\title{
Tuber yield prognosis model and agronomic nitrogen use efficiency of potato cultivars
}

\author{
Paulo Cezar Rezende Fontes ${ }^{1}$, Heder Braun ${ }^{2 *}$, Marcelo Cleón de Castro Silva ${ }^{1}$, Fabrício Silva Coelho ${ }^{1}$, \\ Paulo Roberto Cecon ${ }^{3}$, Fábio Luiz Partelli ${ }^{4}$
}

\author{
${ }^{1}$ Federal University of Viçosa, Department of Plant Sciences, Viçosa, Minas Gerais State, Brazil \\ ${ }^{2}$ Maranhão State University, Agroecology Graduate Program, São Luís, Maranhão State, Brazil \\ ${ }^{3}$ Federal University of Viçosa, Department of Statistics, Viçosa, Minas Gerais State, Brazil \\ ${ }^{4}$ Federal University of Espírito Santo, University Center of North Espírito Santo, Department Plant and Biology \\ Science, São Mateus, Espírito Santo State, Brazil
}

\section{*Corresponding author: hederbraun@gmail.com}

\begin{abstract}
Adjusting nitrogen $(\mathrm{N})$ fertilization rates to crop requirements optimizes $\mathrm{N}$ efficiency and reduces environmental pollution. In accordance with such precision agriculture, methods facilitating rapid and simple real-time crop yield prognostication are desirable. The aims of this study are to establish a prognostic model for tuber yield; early characterization of a properly N-nourished plant and to determine the $\mathrm{N}$ use efficiency by the Asterix and Atlantic potato cultivars. In two separate experiments, on for each cultivar, five pre-planting $\mathrm{N}$ fertilization rates $\left(0,50,100,200\right.$, and $\left.300 \mathrm{~kg} \mathrm{ha}^{-1}\right)$ were evaluated. A randomized complete block design with four replicates per experiment was utilized. Variable chosen for early evaluation, 21 days after emergence, were categorized into four named groups. Group one, linked to chlorophyll (SPAD index and total fourth leaf chlorophyll concentration). Group two, concerning with physiological indexes (leaf, fourth leaf, stem, and shoot dry matter; fourth- and whole-plant leaf area; fourth leaf and plant specific leaf area; and leaf area ratio). The third group linked to fourth leaf $\mathrm{N}$ indexes ( $\mathrm{N}$ concentration per unit dry matter and per unit leaf area, and total $\mathrm{N}$ content). The fourth group referring to $\mathrm{N}$ use efficiency (fourth leaf $\mathrm{N}$ use efficiency and agronomic $\mathrm{N}$ use efficiency). For both cultivars, there are a significant positive correlation between tuber yield and physiologic and $\mathrm{N}$ indexes, while there is a significant negative correlation between tuber yield and $\mathrm{N}$ use efficiency. Regression models utilising the SPAD index as an independent variable are effective in predicting the marketable tuber yield of potato plants, and have the added advantage of real-time determination of the SPAD index in relationship a another methods.
\end{abstract}

Keywords: Solanum tuberosum; precision agriculture; nitrogen fertilization; tuber yield prognosis.

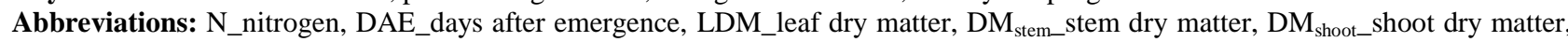
PLA_plant leaf area, SPLA_specific plant leaf area, LAR_leaf area ratio, SPAD_values estimates of chlorophyll content, FL_fourth leaf, FLA_leaf area, SFLA_specific leaf area, FLDM_fourth leaf dry matter, FLTC_fourth leaf total chlorophyll concentration, FLNUE_fourth leaf $\mathrm{N}$ use efficiency, FLN_fourth leaf $\mathrm{N}$ concentration, FLN $\mathrm{A}_{\mathrm{A}}$ fourth leaf $\mathrm{N}$ concentration per unit area, FLNC_fourth leaf N content, MTY_marketable tuber yield, ANOVA_analysis of variance.

\section{Introduction}

There is increasing interest in optimal use of nitrogen $(\mathrm{N})$ for potato crop fertilisation, aimed at improving nutrient use efficiency, crop yield, and profitability. In order to optimise fertilisation, specific $\mathrm{N}$ requirements of the plant must be taken into account. Normally, $\mathrm{N}$ utilisation efficiency ranges from $48 \%$ to $77 \%$ for potato crops (Zebarth et al., 2004). The $\mathrm{N}$ remainder is lost to fixation, immobilization, volatilization as ammonia $\left(\mathrm{NH}_{3}\right)$ gas, and leaching in the form of soluble nitrate $\left(\mathrm{NO}_{3}^{-}\right.$, a groundwater pollutant), each of which also contributes to economic losses (Wang et al., 2015).

In order to increase $\mathrm{N}$ use efficiency and reduce environmental pollution, $\mathrm{N}$ application must be appropriate to the specific needs of the potato plant. In an attempt to increase $\mathrm{N}$ use efficiency in crops, the common practise of applying a single $\mathrm{N}$ fertilization rate over a whole area has been replaced by variable-rate $\mathrm{N}$ fertilization (Roberts et al., 2010 ), or rates adjusted to local area or individual plant $\mathrm{N}$ needs. In recent years, several studies have explored the applicability of the latter two approaches. However, due to system complexity, the success of such approaches remains uncertain (Roberts et al., 2010; Long et al., 2015). Nevertheless, the technology of $\mathrm{N}$ fertilization rates based on site-specific needs is the focus of considerable ongoing research. It has logical appeal and is of commercial interest despite the recognized optimization requirements (Fontes, 2014). Site-specific plant $\mathrm{N}$ needs and real-time $\mathrm{N}$ management align well with precision agriculture, relying on identification of plant $\mathrm{N}$ requirements. The challenge lies in estimating $\mathrm{N}$ fertilization rates and identifying the correct interval between pre-planting $\mathrm{N}$ fertilisation and additional complementary top-dressing $\mathrm{N}$ application (Fontes et al., 2012). Existing systems - which employ sensor-based technology to determine a variable rate of $\mathrm{N}$ application to soil - have been commercialised and are the subject of ongoing study (Samborski et al., 2009). In order to employ top-dressing $\mathrm{N}$ fertilization at the correct rates, via either variable-or fixed-rate application, it is first necessary to determine whether the potato plant requires $\mathrm{N}$ in top- 
dressing. Here, this question is addressed using appropriate early indicators to evaluate the plant $\mathrm{N}$ status (Fontes, 2011). Indices of plant $\mathrm{N}$ status are obtained non-destructively and in real-time, via analysis of petiole sap nitrate levels (Jidong et al., 2007), leaf chlorophyll levels as determined by a portable chlorophyll meter SPAD-502 (Busato et al., 2010; Coelho et al., 2010) and Dualex ${ }^{\circledR}$ equipment (Coelho et al., 2012). Additionally, morphological and physiological plant characteristics (e.g. leaf area and dry matter, leaf number, and plant height), which are easily determined in a nondestructive manner, have been suggested as proxy indexes for plant $\mathrm{N}$ status (complementary to green leaf analysis) (Fontes, 2001; Coelho and Fontes, 2005; Moreira et al., 2011; Yin et al., 2011).

Interpretation of plant $\mathrm{N}$ status requires a reference value. Several factors may influence leaf indicator measurements (Fontes, 2001; Andriolo et al., 2006), including cultivar. In addition, plant $\mathrm{N}$ status indicators must be calibrated for use at an appropriate time, preferably one which is technically desirable and possible to be performed applying of $\mathrm{N}$ in topdressing. In the case of potato crops in Southeast Brazil, topdressing $\mathrm{N}$ application is performed around 20 days after emergence (DAE).

Important variables influencing tuber yield include leaf chlorophyll content, physiological plant characteristics, and soil $\mathrm{N}$ availability. Within certain limitations, some earlyevaluated indicators of potato plant $\mathrm{N}$ status may be used as a valid tool to predict future harvest characteristics, including tuber yield (Coelho et al., 2010). The tuber yield is strongly determined by tuberization, which is the result of various processes in the plant, involving several variables. The enormous demand for early forecasting of culture condition production rates has led to the development of methods based on plant indicators, especially those detectable in real-time. Prediction of tuber yield based on early indicators of plant $\mathrm{N}$ status may be useful in many different situations, such as: establishing a real-time algorithm intended to estimate topdressing $\mathrm{N}$ fertilization rates (Fontes, 2011), early seedling selection during breeding programs, strategic planning of farm management, and organization of seasonal harvests and marketing, among others. Prediction is more feasible in artificially-irrigated crops, such as the potato, where there is less probability of environmental interference after plant sampling for early indicator measurement. The aims of this study are to establish a prognostic model for tuber yield; early characterization of a properly $\mathrm{N}$-nourished plant and to determine the $\mathrm{N}$ use efficiency by the Asterix and Atlantic potato cultivars.

\section{Results and Discussion}

\section{Marketable tuber yield}

An increasing and significant quadratic effect of $\mathrm{N}$ fertilization rates on marketable tuber yield (MTY) was observed for both cultivars (Fig 1). As expected, there was an increase in tuber yield with increasing fertilization, up to an optimal $\mathrm{N}$ fertilization rate corresponding to maximum tuber yield, beyond which no additional benefit occurs and indeed tuber yield declines. For the Asterix and Atlantic potato cultivars, these results suggest that optimal $\mathrm{N}$ fertilization rates (those providing maximum MTY) of $180.33 \mathrm{~kg} \mathrm{ha}^{-1}$ and $205.24 \mathrm{~kg} \mathrm{ha}^{-1}$ respectively, which achieve maximal MTYs of $38.60 \mathrm{t} \mathrm{ha}^{-1}$ and $37.90 \mathrm{t} \mathrm{ha}^{-1}$, respectively. The Altantic cultivar displayed a lower $\mathrm{N}$ use efficiency (NUE - defined as tuber yield per unit of applied $\mathrm{N}$ fertilizer) than the Asterix cultivar, whose $\mathrm{N}$ fertilization rates exceeded that of Atlantic by $25 \mathrm{~kg} \mathrm{ha}^{-1}$ (a $14 \%$ relative difference). However, the optimal $\mathrm{N}$ fertilization rate that provided maximum MTY only differed by $2 \%$ between the two cultivars.

It was previously reported that $\mathrm{N}$ fertilization rates of up to $212 \mathrm{~kg} \mathrm{ha}^{-1}$ and $175 \mathrm{~kg} \mathrm{ha}^{-1}$ increased tuber yield of the Asterix and Atlantic cultivars to $32.3 \mathrm{~kg} \mathrm{ha}^{-1}$ and $33.3 \mathrm{~kg} \mathrm{ha}^{-1}$, respectively (Fontes et al., 2010). The tuber yield values and optimal $\mathrm{N}$ fertilization rates determined by this study generally agree with previous findings of studies carried out under conditions typical to Southeastern Brazil, such as that it is necessary to apply $1.0 \mathrm{~kg} \mathrm{ha}^{-1}$ of $\mathrm{N}$ fertilizer for an expected yield of $190 \pm 40 \mathrm{~kg} \mathrm{ha}^{-1}$ (Fontes et al., 2012), and that above $280 \mathrm{~kg} \mathrm{ha}^{-1}$ additional $\mathrm{N}$ fertilization provides no further gains in tuber yield (Rens et al., 2015), in fact reducing tuber yield.

Plant metabolic limiting factors for NUE maximization differ at high and low $\mathrm{N}$ availability, indicating great potential for NUE improvement (Xu et al., 2012). It follows that precision-application of $\mathrm{N}$ promotes improved physiological characteristics and $\mathrm{N}$ indexes, and thus improves photosynthetic activity, favouring a gain in tuber yield.

In this study, tuber yield of both cultivars declined at high pre-planting $\mathrm{N}$ fertilization rates (e.g. $300 \mathrm{~kg} \mathrm{ha}^{-1}$ ). Supraoptimal $\mathrm{N}$ fertilization rates reduced tuber yield by inhibiting tuberization (Krauss and Marschner, 1982; Krauss, 1985). These authors report that high $\mathrm{N}$ levels together with the photoperiod can inhibit the activity or alter the levels of growth regulators such as gibberellic and abscisic acids. Oparka (1987) and Gibson (2004) reported that high N levels can reduce translocation leaf carbon to tubers, and increases $\mathrm{N}$ flow to new leaves rather than driving tuber production.

\section{The properly $N$-nourished potato plant, evaluated at 21 days after emergence}

The value of each early indicator associated with the optimal $\mathrm{N}$ fertilization rate is indicated (Table 1). These values indicate that both cultivars were properly $\mathrm{N}$-nourished, and are used as reference values. However, soil, climatic, and management factors will influence the optimal value of each variable (Fontes, 2011). Therefore, a critical value ranging from $40 \mathrm{~g} \mathrm{~kg}^{-1}$ to $65 \mathrm{~g} \mathrm{~kg}^{-1}$ of $\mathrm{N}$ is given as the optimum $\mathrm{N}$ concentration in dry matter of the potato fourth leaf (Rodrigues et al., 2000).

Plant leaf area (PLA) values in the properly $\mathrm{N}$-nourished plant were similar in both the Asterix and Atlantic cultivars, at $5657 \mathrm{~cm}^{2} /$ plant and $5396 \mathrm{~cm}^{2} /$ plant, respectively. Lemaire et al. (2008) reported that PLA may be used as an alternative measure to evaluate plant $\mathrm{N}$ status, because both the plant dry matter and the PLA are affected by the same processes involved in $\mathrm{N}$ metabolism during plant growth. Within a wide margin, it can be assumed that the greater the availability of $\mathrm{N}$, the greater the increase in potato PLA. In an experiment carried out under greenhouse conditions, Souza et al. (2012) reported that the PLA value of an adequately N-nourished plant was $2761 \mathrm{~cm}^{2}$, corresponding to an optimum $\mathrm{N}$ fertilization rate of $360 \mathrm{mg} \mathrm{dm}^{-3}$. Yin et al. (2003) reported that the leaf area index (LAI - total one-sided area of leaf tissue per unit ground surface area) is an important parameter for prediction of crop growth and yields. Yin et al. (2003) also demonstrated that the $\mathrm{N}$ present in the plant's leaves is responsible for achieving optimum LAI, and thus for maximizing photosynthesis. Thus, leaf area is strongly influenced by $\mathrm{N}$ availability and may be used as a valid parameter for prediction of tuber yield.

The SPAD index may also be used as a tool to assess plant $\mathrm{N}$ status (Jindong et al., 2007; Busato et al., 2010; Coelho et al., 
Table 1. Values of early evaluated variables (LDM, DM stem $_{\text {, }} \mathrm{DM}_{\text {shoot }}$, PLA, SPLA, LAR) and fourth leaf (SPAD index, FLA, SFLA, FLDM, FLTC, FLNUE, FLN, FLN A $_{\mathrm{A}}$ and FLNC) in adequately N-nourished potato plants for Asterix and Atlantic cultivars.

\begin{tabular}{|c|c|c|c|}
\hline \multirow{2}{*}{ Evaluated Variables } & \multirow{2}{*}{ Unit } & \multicolumn{2}{|c|}{ Cultivars } \\
\hline & & Asterix & Atlantic \\
\hline \multicolumn{4}{|l|}{ Evaluation in plant } \\
\hline LDM - leaf dry matter & $\mathrm{g} / \mathrm{plant}$ & 13.68 & 13.17 \\
\hline $\mathrm{DM}_{\text {stem }}-$ stem dry matter & $\mathrm{g} / \mathrm{plant}$ & 5.62 & 7.61 \\
\hline $\mathrm{DM}_{\text {shoot }}-$ shoot dry matter & $\mathrm{g} /$ plant & 19.83 & 21.75 \\
\hline PLA - leaf area & $\mathrm{cm}^{2} /$ plant & 5656.5 & 5395.5 \\
\hline SPLA - specific leaf area & $\mathrm{cm}^{2} \mathrm{~g}^{-1}$ & 287.52 & 243.84 \\
\hline $\mathrm{LAR}$ - leaf area ratio & $\mathrm{cm}^{2} \mathrm{~g}^{-1}$ & 285.09 & 249.54 \\
\hline \multicolumn{4}{|l|}{ Evaluation in fourth leaf (FL) } \\
\hline SPAD - SPAD index & no units & 44.34 & 44.40 \\
\hline FLA - leaf area & $\mathrm{cm}^{2}$ & 226.04 & 288.24 \\
\hline SFLA - specific leaf area & $\mathrm{cm}^{2} \mathrm{~g}^{-1}$ & 441.97 & 299.11 \\
\hline FLDM - dry matter & $\mathrm{g} / \mathrm{plant}$ & 0.52 & 0.97 \\
\hline FLTC - total clorophyll concentration & $\mathrm{mg} \mathrm{g}^{-1}$ & 8.72 & 7.97 \\
\hline FLNUE - N use efficiency & $\mathrm{g} \mathrm{g}^{-1}$ & 824.80 & 471.00 \\
\hline FLN - N concentration & dag kg-1 & 5.19 & 5.02 \\
\hline $\mathrm{FLN}_{\mathrm{A}}-\mathrm{N}$ concentration per unit area & $\mathrm{g} \mathrm{N} \mathrm{cm}^{-2}$ of leaf & 0.12 & 0.17 \\
\hline FLNC $-\mathrm{N}$ content & $\mathrm{kg} \mathrm{ha}^{-1}$ & 1.43 & 2.56 \\
\hline
\end{tabular}

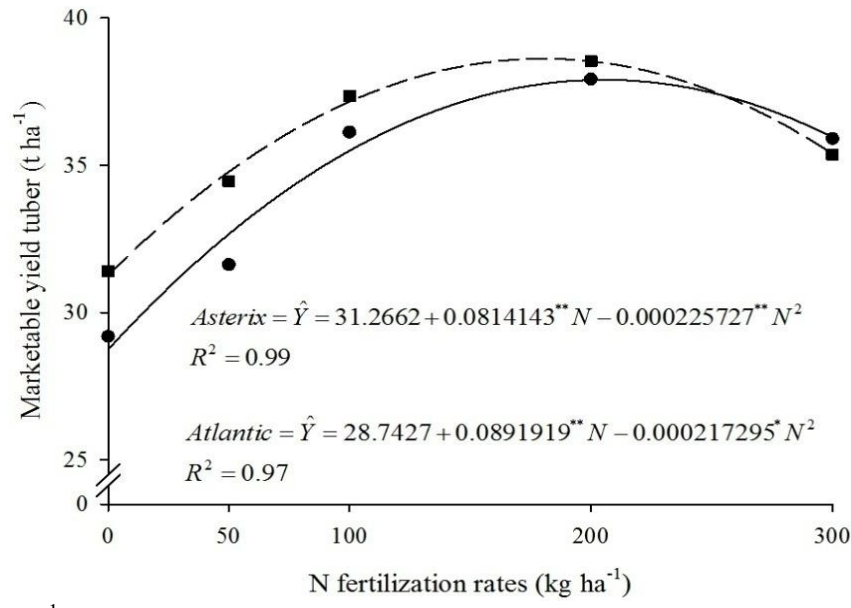

Fig 1. Marketable tuber yield $\left(\mathrm{t} \mathrm{ha}^{-1}\right)$ is dependent on $\mathrm{N}$ fertilisation rates for both Asterix and Atlantic cultivars. ${ }^{* *}$ and ${ }^{*}$ denote $\mathrm{P} \leq$ 0.01 and $\mathrm{P} \leq 0.05$, respectively).

2010; Muñoz-Huerta et al., 2013; Dunn and Goad, 2015; Zheng et al., 2015).

In this study, both agronomic $\mathrm{N}$ use efficiency (AEN) and NUE decreased with increasing $\mathrm{N}$ fertilization rates. AEN ranged from $40.7 \mathrm{~kg} \mathrm{~kg}^{-1}$ to $17.9 \mathrm{~kg} \mathrm{~kg}^{-1}$ for the Asterix cultivar, and $44.6 \mathrm{~kg} \mathrm{~kg}^{-1}$ to $9.5 \mathrm{~kg} \mathrm{~kg}^{-1}$ for the Atlantic cultivar, corresponding to $\mathrm{N}$ fertilization rates of $0 \mathrm{~kg} \mathrm{ha}^{-1}$ to $300 \mathrm{~kg} \mathrm{ha}^{-1}$. NUE ranged from $695 \mathrm{~kg} \mathrm{~kg}^{-1}$ to $118 \mathrm{~kg} \mathrm{~kg}^{-1}$ for the Asterix cultivar, and $653 \mathrm{~kg} \mathrm{~kg}^{-1}$ to $120 \mathrm{~kg} \mathrm{~kg}^{-1}$ for the Atlantic cultivar, corresponding to $\mathrm{N}$ fertilization rates of 50 $\mathrm{kg} \mathrm{ha}^{-1}$ to $300 \mathrm{~kg} \mathrm{ha}^{-1}$. This is in agreement with previous work by Zebarth et al. (2004, 2006, 2008), who also observed a decrease in NUE with increasing $\mathrm{N}$ fertilization rates. Zebarth et al. (2004) attributed NUE variation to variations in $\mathrm{N}$ absorption, and in metabolic processes that influence the efficiency with which the plant uses $\mathrm{N}$ absorbed.

\section{A prognostic model for potato tuber yield}

In the present study, both cultivars displayed a significant positive relationship between MTY (the dependent variable) and all measured indicators (the independent variables), with the exception of some physiological indexes: specific plant leaf area (SPLA) and leaf area ratio (LAR) in the Asterix cultivar, and specific fourth leaf area (SFLA) in the Atlantic cultivar (Table 2). In both cultivars, only fourth leaf $\mathrm{N}$ use efficiency (FLNUE) displayed a negative relationship to MTY. These findings are in agreement with previous literature concerning the Asterix cultivar, where in significant positive correlations were observed between MTY and several variables, including SPAD index, fourth leaf $\mathrm{N}$ (FLN), and fourth leaf total chlorophyll concentration (FLTC) (Coelho et al., 2010).

The tuber yield is determined by the tuberization process which is the result of several other plant processes in which several variables are involved such as related to the chlorophyll, and as well as the related to plant physiological characteristics. It is significantly affected by fluctuations in $\mathrm{N}$ availability.

Among the variables studied, PLA was overall the most highly-correlated with MTY for both the Asterix ( $\mathrm{r}=0.98, \mathrm{P} \leq$ $0.01)$ and Atlantic $(r=0.96, P \leq 0.01)$ cultivars. Using this 
Table 2. Prognostic models for marketable tuber yield (MTY, $\mathrm{kg} \mathrm{ha}^{-1}$ ) as a function of each early-evaluated variable in potato plants $\left(L D M, D_{\text {stem }}, D_{\text {shoot }}\right.$, PLA, SPLA, LAR) and their fourth leaf (SPAD index, FLA, SFLA, FLDM, FLTC, FLNUE, FLN, FLN and FLNC) for Asterix and Atlantic cultivars.

\begin{tabular}{|c|c|c|c|c|}
\hline Cultivars & Variables & $\mathrm{r}$ & Adjusted models & $\mathrm{r}^{2}$ \\
\hline $\begin{array}{l}\text { Asterix } \\
\text { Atlantic }\end{array}$ & MTY with LDM & $\begin{array}{l}0.94^{* *} \\
0.95^{* *}\end{array}$ & $\begin{array}{l}\hat{\mathrm{Y}}=7.66341+2.25201^{* *} \mathrm{LDM} \\
\hat{\mathrm{Y}}=-6.99225+3.38453^{* *} \mathrm{LDM}\end{array}$ & $\begin{array}{l}0.88 \\
0.90\end{array}$ \\
\hline $\begin{array}{l}\text { Asterix } \\
\text { Atlantic }\end{array}$ & MTY with $\mathrm{DM}_{\text {stem }}$ & $0.65^{*}$ & $\begin{array}{l}\hat{\mathrm{Y}}=18.8063+3.24177^{\circ} \mathrm{DM}_{\text {stem }} \\
\hat{\mathrm{Y}}=17.8827+2.48231^{*} \mathrm{DM}_{\text {stem }}\end{array}$ & $\begin{array}{l}0.42 \\
0.58\end{array}$ \\
\hline $\begin{array}{l}\text { Asterix } \\
\text { Atlantic }\end{array}$ & MTY with $\mathrm{DM}_{\text {shoot }}$ & $\begin{array}{l}0.88^{*} \\
0.88^{*}\end{array}$ & $\begin{array}{l}\hat{\mathrm{Y}}=9.43761+1.44924^{*} \mathrm{DM}_{\text {shoot }} \\
\hat{\mathrm{Y}}=4.70848+1.50456^{*} \mathrm{DM}_{\text {shoot }}\end{array}$ & $\begin{array}{l}0.77 \\
0.77\end{array}$ \\
\hline $\begin{array}{l}\text { Asterix } \\
\text { Atlantic }\end{array}$ & MTY with PLA & $\begin{array}{l}0.98^{* *} \\
0.96^{* *}\end{array}$ & $\begin{array}{l}\hat{Y}=15.7999+0.00398493^{*} \text { PLA } \\
\hat{Y}=14.8320+0.00425399^{*} \text { PLA }\end{array}$ & $\begin{array}{l}0.96 \\
0.92\end{array}$ \\
\hline $\begin{array}{l}\text { Asterix } \\
\text { Atlantic }\end{array}$ & MTY with SPLA & $\begin{array}{l}0.28^{\mathrm{NS}^{-}} \\
0.70^{\circ}\end{array}$ & $\begin{array}{l}\mathrm{NS} \\
\hat{\mathrm{Y}}=-23.2662+0.241779^{\circ} \mathrm{SPLA}\end{array}$ & 0.49 \\
\hline $\begin{array}{l}\text { Asterix } \\
\text { Atlantic }\end{array}$ & MTY with LAR & $\begin{array}{l}0.34^{\mathrm{NS}^{-}} \\
0.85^{*}\end{array}$ & $\begin{array}{l}\mathrm{NS} \\
\hat{\mathrm{Y}}=-26.8477+0.148725^{*} \mathrm{LAR}\end{array}$ & 0.72 \\
\hline $\begin{array}{l}\text { Asterix } \\
\text { Atlantic }\end{array}$ & MTY with SPAD & $\begin{array}{l}0.81^{* *} \\
0.94^{* *}\end{array}$ & $\begin{array}{l}\hat{Y}=13.7447+0.530077^{*} \text { SPAD } \\
\hat{Y}=2.37714+0.787351^{* *} \text { SPAD }\end{array}$ & $\begin{array}{l}0.66 \\
0.88\end{array}$ \\
\hline $\begin{array}{l}\text { Asterix } \\
\text { Atlantic }\end{array}$ & MTY with FLA & $\begin{array}{l}0.99^{\circ} \\
0.78^{\circ}\end{array}$ & $\begin{array}{l}\hat{\mathrm{Y}}=19.071+0.0862181^{*} \mathrm{FLA} \\
\hat{\mathrm{Y}}=15.2633+0.0756295^{*} \mathrm{FLA}\end{array}$ & $\begin{array}{l}0.98 \\
0.61\end{array}$ \\
\hline $\begin{array}{l}\text { Asterix } \\
\text { Atlantic }\end{array}$ & MTY with SFLA & $\begin{array}{l}0.91^{*} \\
0.28^{\mathrm{NS}}\end{array}$ & $\begin{array}{l}\mathrm{Y}=8.48969+0.0674334 \text { SFLA } \\
\mathrm{NS}\end{array}$ & $\begin{array}{l}0.83 \\
-\end{array}$ \\
\hline $\begin{array}{l}\text { Asterix } \\
\text { Atlantic }\end{array}$ & MTY with FLDM & $\begin{array}{l}0.88^{*} \\
0.86^{*}\end{array}$ & $\begin{array}{l}\hat{Y}=9.4716+5.42488^{*} \text { FLDM } \\
\hat{Y}=7.65337+30.8357^{*} \text { FLDM }\end{array}$ & $\begin{array}{l}0.77 \\
0.74\end{array}$ \\
\hline $\begin{array}{l}\text { Asterix } \\
\text { Atlantic }\end{array}$ & MTY with FLTC & $\begin{array}{l}0.94^{* *} \\
0.94^{* *}\end{array}$ & $\begin{array}{l}\hat{\mathrm{Y}}=24.2964+1.57311^{*} \text { FLTC } \\
\hat{\mathrm{Y}}=14.1586+2.93405^{* *} \text { FLTC }\end{array}$ & $\begin{array}{l}0.88 \\
0.88\end{array}$ \\
\hline $\begin{array}{l}\text { Asterix } \\
\text { Atlantic }\end{array}$ & MTY with FLNUE & $\begin{array}{l}-0.80^{*} \\
-0.85^{*}\end{array}$ & $\begin{array}{l}\hat{Y}=42.4833-0.00756711^{*} \text { FLNUE } \\
\hat{Y}=53.9754-0.0385270^{*} \text { FLNUE }\end{array}$ & $\begin{array}{l}0.64 \\
0.72\end{array}$ \\
\hline $\begin{array}{l}\text { Asterix } \\
\text { Atlantic }\end{array}$ & MTY with FLN $_{A}$ & $\begin{array}{l}0.60^{\circ} \\
0.68^{\circ}\end{array}$ & $\begin{array}{l}\hat{Y}=26.6293+79.9286^{\circ} \text { FLN }_{A} \\
\hat{Y}=17.1788+107.969^{*} \text { FLN }_{\mathrm{A}}\end{array}$ & $\begin{array}{l}0.36 \\
0.46\end{array}$ \\
\hline $\begin{array}{l}\text { Asterix } \\
\text { Atlantic }\end{array}$ & MTY with FLN & $\begin{array}{l}0.86^{*} \\
0.86^{*}\end{array}$ & $\begin{array}{l}\hat{Y}=24.9401+2.412600^{*} \mathrm{FLN} \\
\hat{\mathrm{Y}}=10.9896+5.10736^{*} \mathrm{FLN}\end{array}$ & $\begin{array}{l}0.74 \\
0.74\end{array}$ \\
\hline $\begin{array}{l}\text { Asterix } \\
\text { Atlantic }\end{array}$ & MTY with FLNC & $\begin{array}{l}0.86^{*--} \\
0.94^{* *}\end{array}$ & $\begin{array}{l}\hat{\mathrm{Y}}=27.5611+6.96549^{*} \text { FLNC } \\
\hat{\mathrm{Y}}=18.7792+7.33235^{* *} \text { FLNC }\end{array}$ & $\begin{array}{l}0.74 \\
0.88\end{array}$ \\
\hline
\end{tabular}

, and ${ }^{\circ}$ : denote non-significant, $\mathrm{P} \leq 0.01, \mathrm{P} \leq 0.05$, and $\mathrm{P} \leq 0.10$, respectively, by t-test

variable, the models proposed to predict the MTY are $\hat{Y}=$ $15.7999+0.00398493^{* *}$ PLA for the Asterix cultivar and $\hat{Y}$ $=14.8320+0.00425399^{*}$ PLA for the Atlantic cultivars (Table 2). Among $\mathrm{N}$ characteristics or indices, fourth leaf $\mathrm{N}$ content (FLNC) was most highly-correlated with MTY (Asterix: $\mathrm{r}=0.86, \mathrm{P} \leq 0.01$; Atlantic: $\mathrm{r}=0.94, \mathrm{P} \leq 0.01$; Table 2).

However, neither PLA nor FLNC can be determined in real time. A measure for which real-time determination is possible is the SPAD index, and using this variable alters the proposed models for prediction of MTY to $\hat{Y}=13.7447+$ $0.530077^{*}$ SPAD index and $\hat{Y}=2.37714+0.787351^{* *}$ SPAD index for the Asterix and Atlantic cultivars, respectively (Table 2). SPAD index is a good predictor to MTY. Instead of the SPAD index, Moreira et al. (2011) and Yin et al. (2011) used plant height as a non-destructive tool for prediction of tuber yield and maize yield, respectively. The latter reported that plant height provides a physiological basis for determination of $\mathrm{N}$ fertilization rates.

However, in the potato crop, knowledge of physiological and $\mathrm{N}$ characteristics or indexes as variable or independent predictors is still poorly explored for development of multiple regression models to predict the MTY. As such, we investigated the use of early indicator variables in conjunction with multiple linear regression to predict potato MTY. As there was no significant interaction between $\mathrm{N}$ fertilization rates and potato cultivars, a common multiple linear regression model was constructed for the two potato cultivars. This model was adjusted in a step-wise manner by backward and was possible to select of physiological indexes (fourth leaf area [FLA], FLDM, LAR, and shoot dry matter $\left[\mathrm{DM}_{\text {shoot }}\right]$ ) or N/chlorophyll indexes (FLNC, SPAD index, and fourth leaf $\mathrm{N}$ concentration per unit area $\left.\left[\mathrm{FLN}_{\mathrm{A}}\right]\right)$. The MTY prognostic model adjusted to contain only physiological indexes as independent variables is given by the equation $\hat{\mathrm{Y}}=7.64026+0,0307125^{*} \mathrm{FLA}-$ $7.60507^{* * *} \mathrm{FLDM}+0.0305934^{* *} \mathrm{LAR}+0.945729^{* *} \mathrm{DM}_{\text {shoot }}$ $\left(\mathrm{R}^{2}=0.66\right)$. The MTY prognostic model adjusted to contain only $\mathrm{N} /$ chlorophyll indexes as independent variables is given by the equation $\hat{\mathrm{Y}}=13.2326+3.17758^{* * *} \mathrm{FLNC}+$ $0.630452^{* *}$ SPAD - 68,7414** FLN $\left(\mathrm{R}^{2}=0.66\right)$.

The physiological index regression model clearly shows that these indexes - with the exception of FLDM - positively influence MTY. MTY is positively influenced by the FLNC and SPAD chlorophyll indexes when physiological indexes (FLDM, LAR, and $\mathrm{DM}_{\text {shoot }}$ ) are held constant. MTY increases by $31 \mathrm{~kg} \mathrm{ha}^{-1}$ for every unit FLA increase. Similarly, while holding $\mathrm{N}$ content (represented by FLNC and FLN $_{\mathrm{A}}$ ) constant, MTY increases by $0.63 \mathrm{t} \mathrm{ha}^{-1}$ for every unit SPAD index increase. We thus assumed the best simple linear regression models to predict MTY would be those in which FLA or FLNC acted as the independent variables (Table 2). Then, to these simple linear regression models were added the effect of physiological or $\mathrm{N}$ indexes. Including the physiological indexes (FLDM, LAR, and $\mathrm{DM}_{\text {shoot }}$ ) as independent variables reduced the fit of data to the model (a $16.5 \%$ reduction in the average coefficient of determination for both cultivars from $r^{2}=0.79$ to $r^{2}=0.66$ ) (Table 2). Similarly, including the $\mathrm{N}$ indexes (SPAD index, 
$\mathrm{FLN}_{\mathrm{A}}$ ) reduced the fit of data to the model (an 18.5\% reduction in the average coefficient of determination for both cultivars from $r^{2}=0.81$ to $\left.r^{2}=0.66\right)$ (Table 2).

Such studies, in which multiple regression models are used to predict MTY, require further optimization and validation. At the present time, simple linear regression models are recommended as they are straightforward and provide a coefficient of determination $\left(\mathrm{r}^{2}\right)$ value in addition to possessing the desired properties for a modelling algorithm.

\section{Materials and Methods}

\section{Growth conditions of the experimental site}

In 2008, two experiments were conducted at an altitude of $693 \mathrm{~m}$ above sea-level, on fields adjacent to the Plant Science Department of the Federal University of Viçosa, Viçosa, Minas Gerais State (latitude $20^{\circ} 45^{\prime} \mathrm{S}$ and longitude $42^{\circ} 51^{\prime}$ E). The predominant climate type in this area is Cwa according to the Koppen classification system (1948), with an annual rainfall of around $1,340 \mathrm{~mm}$ and average relative humidity of $80 \%$. The experiments were performed during the dry season (267.3 $\mathrm{mm}$ of rainfall) with supplementary irrigation. During the experimental period, the average maximum and minimum temperatures were $31.40{ }^{\circ} \mathrm{C}$ and $19.23{ }^{\circ} \mathrm{C}$ respectively, and the average relative humidity was $70.12 \%$. Climate data recorded during the experiment were obtained from the meteorological station of the Agricultural Engineering Department at UFV, located about $3 \mathrm{~km}$ from the experimental area.

The soil of the experimental area was classified as redyellow cambic podzolic. This soil sampling was carried out at a depth of $0-20 \mathrm{~cm}$ for chemical characterization. The soil had the following chemical characteristics: $\mathrm{pH}$ of 6.58 (via $\mathrm{H}_{2} \mathrm{O}$ determination), contained $2.75 \mathrm{dag} \mathrm{kg}^{-1}$ of organic matter, had $0.00 \mathrm{cmol}_{\mathrm{c}} \mathrm{dm}^{-3}$ of exchangeable acidity $\left(\mathrm{Al}^{3+}\right)$, $4.90 \mathrm{cmol}_{\mathrm{c}} \mathrm{dm}^{-3}$ of potential acidity $\left(\mathrm{H}^{+}+\mathrm{Al}^{3+}\right), 7.44 \mathrm{cmol}_{\mathrm{c}}$ $\mathrm{dm}^{-3}$ of effective cation exchange capacity, $12.34 \mathrm{cmol}_{\mathrm{c}} \mathrm{dm}^{-3}$ cation exchange capacity at $\mathrm{pH} 7.0$, and $41.2 \mathrm{mg} \mathrm{dm}^{-3}$ of remaining phosphorus.

\section{Experimental design and conditions}

Two experiments (corresponding to two different Solanum tuberosum cultivars, Asterix and Atlantic) were conducted simultaneously, using a randomized block design with four replicates per experiment. Each experiment evaluated five $\mathrm{N}$ fertilization rates $\left(0,50,100,200\right.$, and $\left.300 \mathrm{~kg} \mathrm{ha}^{-1}\right)$, applied to the soil furrow prior to planting. Each planting plot consisted of 28 plants in four rows, with $0.75 \mathrm{~m}$ spacing between rows, and $0.25 \mathrm{~m}$ spacing between plants. Of the 28 seed potatoes planted, the 10 interior plants were considered the plants of interest, as the lateral two rows and a plant from each end of the central rows acted as plot borders.

\section{Soil preparation, fertilization, and planting}

Maize had been planted without $\mathrm{N}$ fertilization as a soil preconditioning measure (to reduce soil $\mathrm{N}$ availability). After maize harvesting, the soil was limed and plowed, and the upper soil was disked and furrowed. Fertiliser with the following composition was applied to the planting furrows: $1800 \mathrm{~kg} \mathrm{ha}^{-1}$ single superphosphate $\left(18 \% \mathrm{P}_{2} \mathrm{O}_{5}\right), 500 \mathrm{~kg} \mathrm{ha}^{-1}$ potassium chloride $\left(60 \% \mathrm{~K}_{2} \mathrm{O}\right), 200 \mathrm{~kg} \mathrm{ha}^{-1}$ magnesium sulphate $(9 \% \mathrm{Mg}), 10 \mathrm{~kg} \mathrm{ha}^{-1}$ borax $(11 \% \mathrm{~B}), 10 \mathrm{~kg} \mathrm{ha}^{-1}$ zinc sulphate $(22 \% \mathrm{Zn}), 10 \mathrm{~kg} \mathrm{ha}^{-1}$ of copper sulphate $(24 \% \mathrm{Cu})$ and $0.5 \mathrm{~kg} \mathrm{ha}^{-1}$ sodium molybdenate $(39 \% \mathrm{Mo})$. Finally, certified, pre-sprouted seed potato tubers of a uniform size $(\sim 70 \mathrm{~g})$ were hand-planted on 27 July $0.15 \mathrm{~m}$ deep in the prepared furrows, followed by application of carbofuran as an insecticide, and immediate coverage with soil using a hoe.

At 22 days after emergence (DAE), soil was ridged around the base of each plant by hoeing. During the experimental period, insecticides were sprayed at regular intervals for pest control, and irrigation was supplied according to plant requirements, with both insecticide application and irrigation interrupted one week prior to tuber harvesting.

\section{Evaluated variables}

Experimental variables of interest (regarding their reflection of plant $\mathrm{N}$ status and their impact on marketable tuber yield [MTY]) were categorized into four named groups as follows. Group one was linked to chlorophyll: SPAD index and fourth leaf total chlorophyll concentration (FLTC). Group two, concerning with physiological indexes: leaf, fourth leaf, stem, and shoot dry matter (LDM, FLDM, DM stem $_{\text {, and }} \mathrm{DM}_{\text {shoot, }}$ ), fourth- and whole-plant leaf area (FLA, PLA), specific fourth- and whole-plant leaf area (SFLA, SPLA), and leaf area ratio (LAR). The third group linked to fourth leaf $\mathrm{N}$ indexes: $\mathrm{N}$ concentration per unit dry matter (FLN) and per unit leaf area $\left(\mathrm{FLN}_{\mathrm{A}}\right)$, and total $\mathrm{N}$ content $(\mathrm{FLNC})$. The fourth group referring to $\mathrm{N}$ use efficiency: fourth leaf $\mathrm{N}$ use efficiency (FLNUE) and agronomic $\mathrm{N}$ use efficiency (AEN). Variables were investigated as follows. At $21 \mathrm{DAE}$, prior to soil ridging around the base of the plant, two fourth fully expanded leaves (FL) were collected from the plant apex. Five readings were performed on each terminal leaflet of the FL - excluding the mid-rib - using the SPAD-502 portable chlorophyll meter to determine the SPAD index. Soon after determine the SPAD index, ten leaf discs were collected from each fourth leaf, weighed, and homogenized (using a mortar and pestle) in the presence of $\mathrm{CaCO}_{3}$, sand, and $5 \mathrm{~mL} 80 \%$ acetone. The FLTC (concentration, $\mathrm{mg} \mathrm{g}^{-1}$, as a proportion of fresh leaf matter) was quantified by a spectrophotometric method (Lichthenthaler, 1987).

Additionally, at $21 \mathrm{DAE}$, two representative plants were harvested from each plot between $07 \mathrm{~h} 00$ and $09 \mathrm{~h} 00$ for determination of physiological characteristics (LDM, FLDM, $\mathrm{DM}_{\text {shoot }}, \mathrm{DM}_{\text {stem }}$, FLA, PLA, SFLA, SPLA, and LAR). The FLA and the PLA were determined with the aid of a leaf area integrator LI-COR ${ }^{\circledR}$ model LI-3100. Subsequently, the harvested plant sections were placed in paper bags and subjected to forced air ventilation in a $70{ }^{\circ} \mathrm{C}$ oven until constant dry matter was achieved. The LDM, FLDM, and $\mathrm{DM}_{\text {stem }}$ were determined, and the $\mathrm{DM}_{\text {shoot }}$ was obtained by summing the dry matters of the remaining parts of the dried plant. The SFLA and SPLA $\left(\mathrm{cm}^{2} \mathrm{~g}^{-1}\right)$ were calculated as the relationship between leaf area and dry matter. Finally, LAR $\left(\mathrm{cm}^{2} \mathrm{~g}^{-1}\right)$ was calculated as the relationship between PLA and $\mathrm{DM}_{\text {shoot }}$.

Regarding fourth leaf $\mathrm{N}$ indexes, for determination of FLN $\left(\mathrm{g} \mathrm{kg}^{-1}\right)$, sulphuric digestion was carried out, according to the Kjeldahl method, while $\mathrm{FLN}_{\mathrm{A}}\left(\mathrm{g} \mathrm{N} \mathrm{cm}^{-2}\right.$ of leaf) was given by the relationship between FLN $\left(\mathrm{g} \mathrm{g}^{-1}\right)$ and SFLA $\left(\mathrm{cm}^{2} \mathrm{~g}^{-1}\right)$. Subsequently, FLNC $\left(\mathrm{kg} \mathrm{ha}^{-1}\right)$ was obtained by the product between FLN and FLDM.

Regarding $\mathrm{N}$ use efficiency, FLNUE (g DM g ${ }^{-1} \mathrm{~N}$ of leaf) was calculated as described by Zebarth et al. (2004), by calculating the relationship between the DM $\mathrm{DMoot}_{\text {sho }}$ and FLNC. Potato tubers were harvested at 101 days after planting (84 $\mathrm{DAE}$ ), and cured on the ground for two hours prior to transport for weighing to determine MTY $\left(\mathrm{t} \mathrm{ha}^{-1}\right)$. The AEN $\left(\mathrm{kg} \mathrm{kg}^{-1}\right)$ is given by the formula $\mathrm{AEN}=\left(\mathrm{YN}_{\mathrm{x}}-\mathrm{YN}_{0}\right) / \mathrm{N}_{\mathrm{x}}$, 
where $\mathrm{YN}_{\mathrm{x}}$ is the MTY achieved at optimal $\mathrm{N}$ fertilization rates, $\mathrm{YN}_{0}$ is the MTY achieved at a rate of zero $\mathrm{N}$ fertilization, and $\mathrm{N}_{\mathrm{x}}$ is the optimal $\mathrm{N}$ fertilization rate which would facilitate a maximum MTY (Fontes and Araújo, 2007). The AEN still was calculated using the MTY of plots that received 50,100,200, and $300 \mathrm{~kg} \mathrm{ha}^{-1} \mathrm{~N}$ fertilization rates. The $\mathrm{N}$ use efficiency (NUE, $\mathrm{kg} \mathrm{kg}^{-1}$ ), finally, is the ratio of MTY to $\mathrm{N}$ fertilization rate $\left(\mathrm{kg} \mathrm{ha}^{-1}\right)$.

\section{Statistical analyses}

Statistical analyses were performed using SAEG software (SAEG for Statistical Analyses, version 9.1). Data were statistically evaluated by analysis of variance (ANOVA) and regression. The best-fit models were chosen based on biological response, significance of the regression coefficients (using the t-test, $\mathrm{P} \leq 0.10$ ), and value of the coefficient of determination $\left(r^{2}\right)$. The $r^{2}$ was obtained by relationship between regression sum of square and treatment sum of square.

For both the Asterix and Atlantic cultivars, the optimum N fertilization rates - corresponding to maximum tuber yield were calculated by setting the first partial derivative of the $\mathrm{N}$ response curve equal to zero. The optimum $\mathrm{N}$ fertilization rate determined would be the rate that most extension specialists recommend to farmers to maximize crop yield. The critical value of each variable of interest was calculated by substituting the optimum $\mathrm{N}$ fertilization rate in the adjusted equation for all dependent variables as a function of $\mathrm{N}$ fertilization rates, as described by Fontes and Ronchi (2002).

Additionally, Pearson linear correlations ( $r$ ) between the experimentally-determined index values (LDM, DM stem $_{\text {, }}$ FLDM, DM shoot $_{1}$ FLA, PLA, SPLA, SFLA, LAR, SPAD

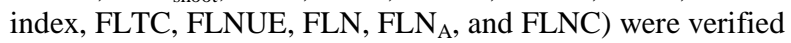
using the MTY. We investigated whether there was a significant correlation between physiological and $\mathrm{N}$ characteristics or indices (the independent variables) and MTY (the dependent variable). Adjusted simple and multiple linear regressions were performed according to the equation $\left(\hat{Y}=\hat{\beta}_{0}+\hat{\beta}_{1} X_{1}+\hat{\beta}_{2} X_{2}+\hat{\beta}_{3} X_{3}+\ldots+\hat{\beta}_{n} X_{n}\right)$. The multiple linear regression model was adjusted in a step-wise manner by "backward elimination" (successive elimination of independent variables).

\section{Conclusions}

A regression model utilising FLA as an independent variable efficiently predicts MTY of potato plants, as do regression models utilising the SPAD index as an independent variable, and the latter had the added advantage of real-time determination of the SPAD index. Properly N-nourished plants of the Asterix and Atlantic cultivars display FLA values of 226.04 and $288.24 \mathrm{~cm}^{2}$, and SPAD index values of 44.34 and 44.40 , respectively. The agronomic efficiency and $\mathrm{N}$ use is reduced by increasing $\mathrm{N}$ fertilization rates. Inferences cannot be generalized to all fields. More data are required to improve precision, due to the ability of environmental variations such as soil fertility, planting season, and climate conditions to impact results. Currently, farmers are not required to adopt technologies that reduce $\mathrm{N}$ leaching into groundwater, but this may become a future requirement. Tuber yield prognosis models based on expected yield will assist in application of only the required amount of $\mathrm{N}$, thereby reducing the amount of $\mathrm{N}$ that can be leached.

\section{Acknowledgments}

The authors would like to thank Coordination of Improvement of Higher Education Personnel (CAPES), National Research Council $(\mathrm{CNPq})$ and Foundation to Research Support in the State of Minas Gerais (FAPEMIG) for the grants, project resources, and scholarships. The corresponding author would like to thank Foundation to Research Support in the State of Maranhão (FAPEMA) for Fellow of Productivity in Research.

\section{References}

Andriolo JL, Bisognin DA, Paula AL, Paula FLM, Godoi RS, Barros GT (2006) Curva crítica de diluição do nitrogênio da cultivar "Asterix" de batata. Pesqui Agropecu Bras. 41(7):1179-1184.

Busato C, Fontes PCR, Braun H, Cecon PR (2010) Seasonal variation and threshold values for chlorophyll meter readings on leaves of potato cultivars. J Plant Nutr. 33:2148-2156.

Coelho EL, Fontes PCR (2005) Índices agronômicos do meloeiro associados à dose adequada de nitrogênio, em ambiente protegido e no campo. Ciênc Agrotec. 29(5):974979.

Coelho FS, Fontes PCR, Puiatti M, Neves JCL, Silva MC de C (2010) Dose de nitrogênio associada à produtividade de batata e índices do estado de nitrogênio na folha. $\mathrm{R}$ Bras Ci Solo. 34:1175-1183.

Coelho FS, Fontes PCR, Finger FL, Cecon PR (2012) Avaliação do estado nutricional do nitrogênio em batateira por meio de polifenóis e clorofila na folha. Pesqui Agropecu Bras. 47(4):584-592.

Dunn BL, Goad C (2015) Effect of foliar nitrogen and optical sensor sampling method and location for determining ornamental cabbage fertility status. HortScience. 50(1):74-77.

Fontes PCR, Silva MC de C, Miranda GV (2012) Statistical models in plant diagnosis and calculating recommended nitrogen rates. In: He Z, Larkin R, Honeycutt W (eds) Sustainable Potato Production: Global Case Studies, New York.

Fontes PCR (2001) Diagnóstico do estado nutricional das plantas. UFV, Viçosa. 122p.

Fontes PCR (2014) Nutrição mineral de hortaliças: horizontes e desafios para um agrônomo. Hortic Bras. 32:325-331.

Fontes PCR (2011) Nutrição mineral de plantas: avaliação e diagnose. Arka Editora, Viçosa, 296p.

Fontes PCR, Araújo C (2006) Use of a chlorophyll meter and plant visual aspect for nitrogen management in tomato fertigation. J Appl Hortic. 8(1):8-11.

Fontes PCR, Braun H, Busato C, Cecon PR (2010) Economic optimum nitrogen fertilization rates and nitrogen fertilization rate effects on tuber characteristics of potato cultivars. Potato Res. 53:167-179.

Fontes PCR, Ronchi CP (2002) Critical values of nitrogen indices in tomato plants grown in soil and nutrient solution determined by different statistical procedures. Pesqui Agropecu Bras. 37(10):1421-1429.

Gibson SI (2004) Sugar and phytohormone response pathways: navigating a signalling network. J Exp Bot. 55(395):253-264.

Jindong WA, Dong B, Rosen CJ, Bauer ME (2007) Comparison of petiole nitrate concentrations, SPAD chlorophyll readings, and QuickBird satellite imagery in detecting nitrogen status of potato canopies. Field Crop Res. 101(1):96-103. 
Krauss A, Marschner H (1982) Influence of nitrogen nutrition, daylength, and temperature on contents of gibberellic and abscisic acid and on tuberization in potato plants. Potato Res. 25(1):13-21.

Krauss A (1985) Interaction of nutrients and tuberization. In: Li PH. Potato Physiology. London, Academic Press, 586p.

Köpen W (1948) Climatologia. Buenos Aires: Gráfica Panamericana. 478p.

Oparka KJ, Davies HV, Prior DAM (1987) The influence of applied $\mathrm{N}$ on export and partitioning of current assimilate by field-grown potato plants. Ann Bot. 59(3):484-488.

Lemaire G, Jeuffroy M-H, Gastal F (2008) Diagnosis tool for plant and crop $\mathrm{N}$ status in vegetative stage. Theory and practices for crop N management. Eur J Agron. 28(4):614624.

Lichthenthaler HK (1987) Chlorophylls and carotenoids: pigments of photosynthetic biomembranes. San Diego, Academic Press.

Long DS, Whitmus JD, Engel RE, Brester GW (2015) Net returns from terrain-based variable-rate nitrogen management on dryland spring wheat in northern Montana. Agron J. 107(3):1055-1067.

Moreira MA, Fontes PCR, Cecon PR, Araújo RF (2011) Índices para avaliar o estado de nitrogênio da batata multiplicada por distintos materiais propagativos. R Ceres. 58(3):384-392.

Muñoz-Huerta RF, Guevara-Gonzalez RG, Contreras-Medina LM, Torres-Pacheco I, Prado-Olivarez J, OcampoVelazquez RV (2013) A Review of methods for sensing the nitrogen status in plants: advantages, disadvantages and recent advances. Sensors. 13(8):10823-10843.

Rens LR, Zotarelli L, Cantliffe DJ, Stoffella PJ, Gergela DM, Fourman D (2015) Biomass accumulation, marketable yield, and quality of Atlantic potato in response to nitrogen. Agron J. 107(3):931-942.

Roberts DF, Kitchen NR, Scharf PC, Sudduth KA (2010) Will variable-rate nitrogen fertilization using corn canopy reflectance sensing deliver environmental benefits? Agron J. 102(1):85-95.

Rodrigues FA, Fontes PCR, Pereira PRG, Martinez HEP (2000) Crescimento e teor crítico de $\mathrm{N}-\mathrm{NO}_{3}$ na seiva da batateira cultivada em solução nutritiva. Hortic Bras. 18:766-767.

Saeg (2007) Sistema para Análises Estatísticas, Versão 9.1: Fundação Arthur Bernardes, UFV, Viçosa
Samborski SM, Tremblay N, Fallon E (2009) Strategies to make use of plant sensors-based diagnostic information for nitrogen recommendations. Agron J. 101(4):800-816.

Souza C. de B. dos S, Fontes PCR, Moreira MA, Puiatti M, Martinez HEP, Araújo RF (2012) Production of basic potato seed minitubers in substrate and different nitrogen rates. R Ceres. 59(6):850-858.

Yin X, Lantinga EA, Schapendonk AHCM, Zhong X (2003) Some quantitative relationships between leaf area index and canopy nitrogen content and distribution. Ann Bot. 91(7):893-903.

Yin X, Mcclure MA, Jaja N, Tyler DD, Hayes RM (2011) Inseason prediction of corn yield using plant height under major production systems. Agron J. 103(3):923-929.

Wang H, Gao J-e, Li X-h, Zhang S-l, Wang H-j (2015) Nitrate accumulation and leaching in surface and ground water based on simulated rainfall experiments. PlosOne. 10(8):1-18.

Zebarth BJ, Tai G, Tarn R de, Milburn PH (2004) Nitrogen use efficiency characteristics of commercial potato cultivars. Can J Plant Sci. 84:589-598.

Zebarth BJ, Arsenault WJ, Sanderson JB (2006) Effect of seedpiece spacing and nitrogen fertilization on tuber yield, yield components and nitrogen use efficiency parameters of two potato cultivars. Am J Potato Res. 83:289-296.

Zebarth BJ, Tarn TR, Jong H, Murphy A (2008) Nitrogen use efficiency characteristics of andígena and diploid potato selections. Am J Potato Res. 85:210-218.

Zheng H-li, Liu Y-c, Qin Y-l, Chen Y, Fan M-s (2015) Establishing dynamic thresholds for potato nitrogen status diagnosis with SPAD chlorophyll meter. J Integrative Agric. 14(1):190-195. 